OPEN ACCESS

Approved by:

Anwar Huq,

University of Maryland

College Park, USA

*Correspondence:

Frontiers Editorial Office

editorial.office@frontiersin.org

Specialty section: This article was submitted to

Environmental Health,

a section of the journal

Frontiers in Public Health

Received: 17 July 2016

Accepted: 17 July 2016

Published: 20 July 2016

Citation:

Frontiers Editorial Office (2016)

Retraction: Human and

Environmental Dangers Posed by

Ongoing Global Tropospheric

Aerosolized Particulates

for Weather Modification.

Front. Public Health 4:156.

doi: 10.3389/fpubh.2016.00156

\section{Retraction: Human and} Environmental Dangers Posed by Ongoing Global Tropospheric Aerosolized Particulates for Weather Modification

\section{Frontiers Editorial Office*}

\section{A retraction of the Original Research Article}

Human and Environmental Dangers Posed by Ongoing Global Tropospheric Aerosolized Particulates for Weather Modification

by Herndon JM. Front Public Health (2016) 4:139. doi: 10.3389/fpubh.2016.00139

The journal retracts the 30 June 2016 article cited above. Based on information discovered after publication and reported to Frontiers in July 2016, the article was examined, revealing that the complaints were valid and that the article does not meet the standards of editorial and scientific soundness for Frontiers in Public Health. The retraction of the article was approved by the Field Chief Editor of Frontiers in Public Health and the Specialty Chief Editor of Environmental Health. The author considers the retraction to be unwarranted and therefore does not agree to the statement.

Copyright (C) 2016 Frontiers Editorial Office. This is an open-access article distributed under the terms of the Creative Commons Attribution License (CC BY). The use, distribution or reproduction in other forums is permitted, provided the original author(s) or licensor are credited and that the original publication in this journal is cited, in accordance with accepted academic practice. No use, distribution or reproduction is permitted which does not comply with these terms. 